\title{
Plural Form in Franchising: An Incomplete Contracting Approach
}

\author{
George Hendrikse and Tao Jiang
}

\begin{tabular}{|l|l|}
\hline \multicolumn{2}{|l|}{ ERIM REPORT SERIES RESEARCH IN MANAGEMENT } \\
\hline ERIM Report Series reference number & ERS-2005-090-ORG \\
\hline Publication & December 2005 \\
\hline Number of pages & 21 \\
\hline Persistent paper URL & \\
\hline Email address corresponding author & tjiang@rsm.nl \\
\hline Address & Erasmus Research Institute of Management (ERIM) \\
& RSM Erasmus University / Erasmus School of Economics \\
& Erasmus Universiteit Rotterdam \\
& P.O.Box 1738 \\
& 3000 DR Rotterdam, The Netherlands \\
& Phone: $\quad+31104081182$ \\
& Fax: $\quad+31104089640$ \\
& Email: info@erim.eur.nl \\
& Internet: $\quad$ www.erim.eur.nl \\
\hline
\end{tabular}

Bibliographic data and classifications of all the ERIM reports are also available on the ERIM website: www.erim.eur.nl 


\section{ERASMUS RESEARCH INSTITUTE OF MANAGEMENT}

\section{REPORT SERIES}

\section{RESEARCH IN MANAGEMENT}

\begin{tabular}{|l|l|}
\hline \multicolumn{2}{|l|}{ ABSTRACT AND KEYWORDS } \\
\hline Abstract & $\begin{array}{l}\text { Plural form franchising is modeled from an incomplete contracting perspective. Complete } \\
\text { franchising is the unique, efficient governance structure only when the plural form externality is } \\
\text { limited and the costs of investment are low for both franchisees. Governance structure choice is } \\
\text { irrelevant when the costs of investment are high for all franchisees, because no franchisee will } \\
\text { invest. Finally, a plural form governance structure is the unique, efficient equilibrium in all other } \\
\text { cases because the power allocated to independent franchisees makes them confident that they } \\
\text { will be able to recoup their investments. Not locational or other differences between units are } \\
\text { necessary for the emergence of plural form franchising, but positive externalities being specific } \\
\text { for the plural form. }\end{array}$ \\
\hline Free Keywords & Incomplete Contracting, Franchising, Plural Form \\
\hline Availability & $\begin{array}{l}\text { The ERIM Report Series is distributed through the following platforms: } \\
\text { Academic Repository at Erasmus University (DEAR), DEAR ERIM Series Portal } \\
\text { Social Science Research Network (SSRN), SSRN ERIM Series Webpage } \\
\text { Research Papers in Economics (REPEC), REPEC ERIM Series Webpage }\end{array}$ \\
\hline Classifications & $\begin{array}{l}\text { The electronic versions of the papers in the ERIM report Series contain bibliographic metadata } \\
\text { by the following classification systems: } \\
\text { Library of Congress Classification, (LCC) LCC Webpage } \\
\text { Journal of Economic Literature, (JEL), JEL Webpage } \\
\text { ACM Computing Classification System CCS Webpage } \\
\text { Inspec Classification scheme (ICS), ICS Webpage }\end{array}$ \\
\hline
\end{tabular}




\title{
Plural Form in Franchising: An Incomplete Contracting Approach
}

\author{
George Hendrikse \\ Tao Jiang ${ }^{1}$
}

Date: October 7, 2005

\begin{abstract}
Plural form franchising is modeled from an incomplete contracting perspective. Complete franchising is the unique, efficient governance structure only when the plural form externality is limited and the costs of investment are low for both franchisees. Governance structure choice is irrelevant when the costs of investment are high for all franchisees, because no franchisee will invest. Finally, a plural form governance structure is the unique, efficient equilibrium in all other cases because the power allocated to independent franchisees makes them confident that they will be able to recoup their investments. Not locational or other differences between units are necessary for the emergence of plural form franchising, but positive externalities being specific for the plural form.
\end{abstract}

Keywords: Incomplete contracting, franchising, plural form

\footnotetext{
${ }^{1}$ George Hendrikse and Tao Jiang are at the Rotterdam School of Management, Erasmus University Rotterdam, ghendrikse@rsm.nl and tjiang@rsm.nl. The paper has benefited from the comments during the EMNET 2005 conference at the Cornivus University of Budapest.
} 


\section{Introduction}

A franchise is a vertical relationship between a franchisor and many franchisees. Combs, e.a. (2004, P907) define that "In franchising, one firm (the franchisor) sells the right to market goods or services under its brand name and using its business practices to a second firm (the franchisee)". Franchising is an important phenomenon. In 1998, there were nearly $\$ 850$ billion in sales of franchised goods and services at over 700,000 US franchise locations. And in the year 2000, franchises made up an estimated \$1 trillion in annual retail sales (Franchise Funding, 2004). According to Michael (1996), sales through franchise have accounted for a significant portion in the following industries: printing and copying ( $71 \%$ of sales), tax preparation $(67 \%)$, specialty food retailing $(55 \%)$, restaurants $(46 \%)$.

Various aspects of franchising are not well understood. Hendrikse and Windsperger (2004) identify topics like governance of franchises (bottom-up franchises, plural form), Gibrat's law, cognition, and complementarity. This article will focus on plural form franchising. It entails that some outlets are owned by franchisor, while other stores are owned by franchisees. Standard economic theory predicts the convergence of governance structures over time, i.e. the selection process of the market winnows out the efficient governance structure. Accordingly, some authors (e.g. Gallini and Lutz 1992; Scott, 1995; Oxenfeldt and Kelly, 1969; Caves and Murphy 1976; Norton, 1988) argue that the dual ownership structure is a transitory phenomenon. They predict that in the long run, one organizational structure, either wholly owned or wholly franchised will prevail and dominate. Explanations based on resources constraint, either capital, managerial talent, or local market information, predict that as the chains become mature, the percentage of company owned outlets should increase (Oxenfeldt and Kelly, 1969; Caves and Murphy 1976; Norton, 1988). On the contrary, signaling theory gives an opposite prediction (Gallini and Lutz 1992; Lafontaine, 1993). In reality, however, we often observe a relatively stable distribution of franchise and company-owned outlets within one network (Lafontaine and Shaw, 2005).

Horizontal as well as vertical externalities exist in franchising networks (Willianson, 1981; Dnes, 1993; Dnes and Garoupa, 2005). These externalities can be also negative or positive. The most prominent example of a negative externality is free-riding in franchises. Free-riding originates from opportunistically using the common brand name by the various franchisees (Caves and Murphy, 1976; Rubin, 1978; Klein, 1980). For example, on one hand a franchisee may horizontally free ride upon other franchisees' efforts (Rubin, 1978), and on the other hand she may vertically free ride upon the franchisor's system-wide promotional efforts as well (Mathewson and Winter, 1985). There are also positive externalities, like organizational learning and innovation (Bradach, 1997 and 1998; Sorenson and Sorensen, 2001; Lewin-Solomon, 1999; Cliquet and Nguyen, 2004).

These externalities depend on the choice of single or plural form franchising. Bradach (1998) examines complementarities between the company-owned and franchised units. He argues that plural form may help franchise networks to overcome four strategic challenges: (1) growth; adding new franchised units may help franchisors to overcome growth constrains, (2) uniformity; a ratcheting process is created in franchising chains, where company-owned units and franchised units set performance benchmarks for each 
other, (3)local responsiveness, which is enhanced by the franchisee's local response to local customers and the market-pressure processes, and (4) system-wide adaptation to change; it is improved by the mutual learning process because plural form can generate more diverse ideas. Franchisees are influenced by the commitment and the results of company-owned units; and the company-owned units benefit from the challenge and post decision insights offered by the franchised units. So, the plural form may be superior to the single form because it leverages the strengths and ameliorate the weaknesses of each single form in order to maintain quality and homogeneity of the business concept throughout the entire franchise, while promoting innovation at the same time.

Sorenson and Sorensen (2001) explain plural form in franchising from the perspective of exploration and exploitation paradox. Franchisees have more incentives to "exploration" and company managers are more possible to be "exploitation". In the context of franchising, 'exploration' refers to the capabilities of innovation and local market knowledge learning, while 'exploitation' refers to the capabilities of controlling quality and executing administrative exercises. The mix of company-owned units and franchised units can affect the balance between centralization and standardization through organizational learning, thereby enhancing the franchise chain's efficiency and performance.

There are also literatures arguing that a plural form franchise has an advantage over a single form arrangement regarding innovation. Lewin-Solomon (1999) argues that franchisors keep a proportion of company-owned units as a commitment device in order to give franchisees enough incentives to innovate. As the interest of the franchisor is aligned with the franchisees', the franchisor can testify the innovations' profitability by testing them first in company-owned units, thereby persuading franchisees to implement it. Cliquet and Nguyen (2004) stress that plural form play an important role in the three stages of innovation process, such as innovation generation, innovation testing and innovation implementation. They argue that franchisees are quite important in generating new ideas because they are closer to local markets and have higher incentives to improve performance than the company managers. On the other hand, company-owned units are considered to important in testing and implementing the innovations.

This article addresses dual distribution in franchising from a governance perspective. Governance concerns the organization of transactions, whereas a governance structure consists of a collection of rules structuring the transactions between the various stakeholders. Franchising is an example of a governance structure. It is a vertical relationship between parties in two stages of a production chain. Other examples of governance structures are investor owned enterprises, worker-controlled firms, cooperatives, mutuals, joint ventures, networks, foundations, and public enterprises.

A standard way of delineating a governance structure is to distinguish income and decision rights (Hansmann, 1996). ${ }^{2}$ Income rights address the question 'How are benefits and costs allocated?', i.e. they specify the rights to receive the benefits, and obligations to pay the costs, that are associated with the use of an asset. For example, a franchise has to choose the level of the royalty rate and the franchise fee. Other important themes regarding income rights are financing, cost allocation schemes, and the effects of horizontal as well as vertical competition.

\footnotetext{
${ }^{2}$ Saloner e.a. (2001) uses the distinction incentives and authority.
} 
Decision rights in the form of authority and responsibility address the question 'Who has authority or control?', i.e. they concern all rights and rules regarding the deployment and use of assets. Governance is relevant next to (formal) contracts because contracts are in general incomplete, due to the complexity of the transaction or the vagueness of language. ${ }^{3}$ Contractual incompleteness is dealt with by (the choice of) organization because it allocates authority to somebody to decide in circumstances not covered by the contract. Important themes regarding authority are its allocation ('makeor-buy' decision), formal versus real authority, relational contracts, access, decision control (ratification, monitoring), decision management (initiation, implementation), task design, conflict resolution, and enforcement mechanisms.

The focus in this article is on the allocation of decision rights in franchises. There are system-specific assets, like the brand name, and decisions have to be taken regarding the network's production, marketing, and service in order to improve its brand name value and maintain system-wide standardization. There are also local-specific assets, like knowledge about the local market, and decisions have to be taken regarding local operations. Plural form franchising is special because there are two decision rights regimes within one organization, i.e. local managers as employees of company-owned outlets and managers as employers/entrepreneurs of independent outlets, as well as different income rights for these two classes of franchisees.

Transaction cost economics argues that the costs differences that are measured by asset specificity, frequency and uncertainty may explain the different ownership structure of the individual units. Brickley, Dark, and Weisbach (1991), Gallini and Lutz (1992), Mathewson and Winter (1994) and Lutz (1995) point out the importance of ownership in determining the incentives under different structures. Primarily the influence of transaction specificity on the tendency toward vertical integration by company-owned units was investigated. The risk of opportunism by the franchisor is reduced by the franchisee's outlet-specific investments; as a result, the percentage of company-owned units decreases.

According to the property rights theory, the allocation of residual income rights depends on the importance of intangible system-specific and local market assets. The percentage of company-owned outlets (PCO) is expected to be higher when franchisor's intangible assets are more important than franchisee's intangible assets for generating residual income, because more property rights should be transferred to franchisor. Therefore, PCO is positively related to the intangible system-specific assets and negatively related to the intangible local market assets. Ownership redirection cannot be accomplished because of the non-contractibility of both franchisor and franchisee's intangible assets, and consequently leads to a stable dual distribution of company-owned and franchised outlets (Windsperger, 2004). Franchising increases franchisors' and franchisees' ex ante incentives; and at the same time it also creates ex post incentive conflicts between them. Under a dual ownership structure, the allocation pattern of decision rights may alleviate the incentive conflicts. For example, franchisee receives higher investment incentive from a low royalty, which weakens franchisor's incentive.

\footnotetext{
${ }^{3}$ Contracts are usually distinguished between complete and incomplete contracts (Hart, 1995). Complete contracts specify all relevant aspects of an exchange, whereas an incomplete contract assigns authority to somebody to decide in circumstances not covered by the formal contract.
} 
Franchisor may compensate this disincentive effects through keeping a proportion of company-owned outlets (Windsperger and Yurdakul, 2005).

In this article, an incomplete contracting model of dual distribution in franchising is presented along the lines of Hart and Moore (1990). Three parties are distinguished: the franchisor with investment opportunity of value $\mathrm{A}$, a franchisee with investment opportunity of value B and a franchisee with investment opportunity of value $C(>B)$. A parameter $\sigma$ captures an externality being specific to the plural form. Complete franchising is the unique, efficient governance structure only when the plural form externality is limited and the costs of investment are low for both franchisees. Governance structure choice is irrelevant when the costs of investment are high for all franchisees, because no franchisee will invest. Finally, a plural form governance structure is the unique, efficient equilibrium in all other cases because the power allocated to independent franchisees makes them confident that they will be able to recoup their investments. Not locational or other differences between units are necessary for the emergence of plural form franchising, but positive externalities being specific for the plural form.

The paper is organized as follows. Section 2 presents the model. In section 3, the incentive to invest is determined for each party in each governance structure. Section 4 addresses the choice of governance structure. Section 5 concludes.

\section{Model}

The choice of governance structure and the incentive to invest is analyzed from an incomplete contracting perspective. The incomplete contracting perspective argues that a distinction has to be made between observable and verifiable actions, i.e. not all observable actions are also verifiable by a third party (Grossman and Hart, 1986). Only verifiable actions can be included in a meaningful contract. The classic incomplete contracting model of Hart and Moore (1990) consists of a non-cooperative game of two stages: a governance structure stage and an investment stage. The choice of governance structure determines the bargaining strength of each party in the first stage, while bargaining positions are determined by the choice of the level of investment in the second stage. The relationship between the first and the second stage is that the allocation of bargaining power by the choice of governance structure in the first stage determines the incentive to invest in the second stage.

We consider the choice of franchising or company ownership in a two-store chain. Three parties are distinguished: a franchisor choosing to produce a brand / trademark of value $\mathrm{A}$, a seller deciding to add value $\mathrm{B}$ to the product / service of the franchisor, and a seller deciding to add value $\mathrm{C}(>\mathrm{B})$ to the product / service of the franchisor. Figure 1 presents these three parties. The top box is the franchisor, while the bottom-left (right) box is seller $\mathrm{B}(\mathrm{C})$.

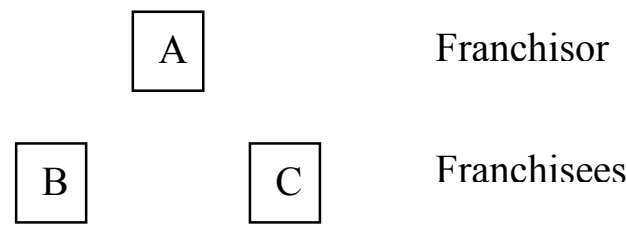

Figure 1: The three parties 
The focus is on the ownership of the local units and the trademark. Figure 2 distinguishes four governance structures. Governance structure I entails that all outlets are company owned. There are two plural form governance structures. The high value franchisee is independent in governance structure II, while the low value franchisee is independent in governance structure III. All franchisees are independent in governance structure IV. A cross in a box indicates that this party has the residual control / power / authority to decide in unforeseen circumstances (Grossman and Hart, 1986; Hart and Moore, 1990).

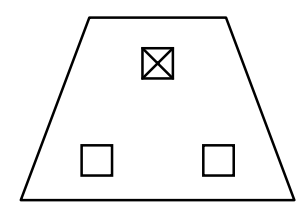

I. Wholly company owned

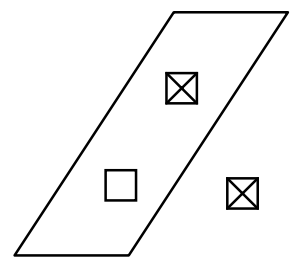

II. Plural form with low value manager



III. Plural form with high value manager

\section{$凶$}

凶 $\quad$

IV. Wholly franchised

Figure 2: Four governance structures 
It is assumed that both parties sell one unit of the product. They decide only about adding additional value to the product. A parameter $\sigma$ is introduced to capture positive externalities being specific to the plural form as described by Bradach (1997), like system wide learning $(\sigma>1)$ and competition / ratcheting / benchmarking $(\sigma>1)$. (The case $\sigma<$ 1 will also be analyzed, i.e. negative externalities being specific to the plural form.) Define $\mathrm{x}_{1}\left(\mathrm{x}_{2}, \mathrm{x}_{3}\right)$ as the sunk costs by the franchisor (franchisee $\mathrm{B}$, franchisee $\mathrm{C}$ ), where $\mathrm{x}_{\mathrm{i}}$ is either 0 or 1 . Table 1 summarizes these ingredients of the model by presenting the characteristic function form when all parties invest for all governance structures $(G)$.

\begin{tabular}{|c|c|c|c|c|}
\hline $\mathrm{x}$ & $(1,1,1)$ & $(1,1,1)$ & $(1,1,1)$ & $(1,1,1)$ \\
\hline $\mathrm{G}$ & I & II & III & IV \\
\hline $\mathrm{v}(1)$ & $\mathrm{A}+\mathrm{B}+\mathrm{C}$ & $\mathrm{A}+\sigma \mathrm{B}$ & $\mathrm{A}+\sigma \mathrm{C}$ & A \\
\hline $\mathrm{v}(2)$ & 0 & 0 & $\sigma \mathrm{B}$ & B \\
\hline $\mathrm{v}(3)$ & 0 & $\sigma \mathrm{C}$ & 0 & $\mathrm{C}$ \\
\hline $\mathrm{v}(12)$ & $\mathrm{A}+\mathrm{B}+\mathrm{C}$ & $\mathrm{A}+\sigma \mathrm{B}$ & $\mathrm{A}+\sigma \mathrm{B}+\sigma \mathrm{C}$ & $A+B$ \\
\hline $\mathrm{v}(13)$ & $\mathrm{A}+\mathrm{B}+\mathrm{C}$ & $\mathrm{A}+\sigma \mathrm{B}+\sigma \mathrm{C}$ & $\mathrm{A}+\sigma \mathrm{C}$ & $\mathrm{A}+\mathrm{C}$ \\
\hline $\mathrm{v}(23)$ & 0 & $\sigma \mathrm{C}$ & $\sigma \mathrm{B}$ & $\mathrm{B}+\mathrm{C}$ \\
\hline $\mathrm{v}(123)$ & $\mathrm{A}+\mathrm{B}+\mathrm{C}$ & $\mathrm{A}+\sigma \mathrm{B}+\sigma \mathrm{C}$ & $\mathrm{A}+\sigma \mathrm{B}+\sigma \mathrm{C}$ & $\mathrm{A}+\mathrm{B}+\mathrm{C}$ \\
\hline
\end{tabular}

Table 1: Characteristic function form when all parties invest

\section{Investment}

This section consists of two parts. Section 3.1 determines the payoff for each player in every governance structure when all parties invest. Section 3.2 presents the subgame perfect equilibrium investment choices.

\subsection{Investment incentives}

The characteristic functions of the previous section determine the incentive to invest. We use, like Hart and Moore (1990), the Shapley value (Shapley, 1953) in order to determine the value of each player in each governance structure for all combinations of investment decisions. These values / payoffs reflect the distribution of bargaining power. The economic interpretation of the Shapley value is that it provides a measure for the incentive intensity to invest. Table 2 presents the Shapley values belonging to the characteristic functions of table 1 . 


\begin{tabular}{|c|c|c|c|c|}
\hline $\mathrm{X}$ & $\mathrm{G}$ & Shapley value franchisor & Shapley value seller B & Shapley value seller C \\
\hline$(1,1,1)$ & $\mathrm{I}$ & $\mathrm{A}+\mathrm{B}+\mathrm{C}$ & 0 & 0 \\
\hline$(1,1,1)$ & II & $\mathrm{A}+\sigma \mathrm{B}$ & 0 & $\sigma \mathrm{C}$ \\
\hline$(1,1,1)$ & III & $\mathrm{A}+\sigma \mathrm{C}$ & $\sigma \mathrm{B}$ & 0 \\
\hline$(1,1,1)$ & IV & $\mathrm{A}$ & $\mathrm{B}$ & $\mathrm{C}$ \\
\hline
\end{tabular}

Table 2: Shapley values when all parties invest

\subsection{Investment choices}

The above results are incomplete regarding the choices that will be made by the various parties. The reason is that the investment decisions are exogenous. The costs of investment have to be taken into account in order to determine the investment decisions. Define $\mathrm{k}_{1}\left(\mathrm{k}_{2}, \mathrm{k}_{3}\right)$ as the sunk costs by the franchisor (buyer B, buyer C). All payoffs in the game are now specified. Appendix 1 depicts the extensive form of the game. The subgame perfect equilibrium investment decisions are determined by the method of backward induction. These decisions and the associated payoffs are presented in figure 3 (when $\mathrm{k}_{1} \leq \mathrm{A}$ and $\sigma>1$ ).

\begin{tabular}{|c|c|c|}
\hline $\begin{array}{l}\text { I: }\left(A-k_{1}, 0,0\right) \\
\text { II: }\left(A-k_{1}, 0,0\right) \\
\text { III: }\left(A-k_{1}, \sigma B-k_{2}, 0\right) \\
\text { IV: }\left(A-k_{1}, B-k_{2}, 0\right)\end{array}$ & $\begin{array}{l}\text { I: }\left(A-k_{1}, 0,0\right) \\
\text { II: }\left(A-k_{1}, 0,0\right) \\
\text { III: }\left(A-k_{1}, \sigma B-k_{2}, 0\right) \\
\text { IV: }\left(A-k_{1}, 0,0\right)\end{array}$ & $\begin{array}{l}\text { I: }\left(A-k_{1}, 0,0\right) \\
\text { II: }\left(A-k_{1}, 0,0\right) \\
\text { III: }\left(A-k_{1}, 0,0\right) \\
\text { IV: }\left(A-k_{1}, 0,0\right)\end{array}$ \\
\hline $\begin{array}{l}\text { I: }\left(A-k_{1}, 0,0\right) \\
\text { II: }\left(A-k_{1}, 0, \sigma C-k_{3}\right) \\
\text { III: }\left(A-k_{1}, \sigma B-k_{2}, 0\right) \\
\text { IV: }\left(A-k_{1}, B-k_{2}, 0\right)\end{array}$ & $\begin{array}{l}\text { I: }\left(A-k_{1}, 0,0\right) \\
\text { II: }\left(A-k_{1}, 0, \sigma C-k_{3}\right) \\
\text { III: }\left(A-k_{1}, \sigma B-k_{2}, 0\right) \\
\text { IV: }\left(A-k_{1}, 0,0\right)\end{array}$ & $\begin{array}{l}\text { I: }\left(A-k_{1}, 0,0\right) \\
\text { II: }\left(A-k_{1}, 0, \sigma C-k_{3}\right) \\
\text { III: }\left(A-k_{1}, 0,0\right) \\
\text { IV: }\left(A-k_{1}, 0,0\right)\end{array}$ \\
\hline \multirow[t]{2}{*}{$\begin{array}{l}\text { I: }\left(A-k_{1}, 0,0\right) \\
\text { II: }\left(A-k_{1}, 0, \sigma C-k_{3}\right) \\
\text { III: }\left(A-k_{1}, \sigma B-k_{2}, 0\right) \\
\text { IV: }\left(A-k_{1}, B-k_{2}, C-k_{3}\right)\end{array}$} & $\begin{array}{l}\text { I: }\left(A-k_{1}, 0,0\right) \\
\text { II: }\left(A-k_{1}, 0, \sigma C-k_{3}\right) \\
\text { III: }\left(A-k_{1}, \sigma B-k_{2}, 0\right) \\
\text { IV: }\left(A-k_{1}, 0, C-k_{3}\right)\end{array}$ & $\begin{array}{l}\text { I: }\left(A-k_{1}, 0,0\right) \\
\text { II: }\left(A-k_{1}, 0, \sigma C-k_{3}\right) \\
\text { III: }\left(A-k_{1}, 0,0\right) \\
\text { IV: }\left(A-k_{1}, 0, C-k_{3}\right)\end{array}$ \\
\hline & $\begin{array}{l}\text { B } \\
\text { e perfect equilibrium }\end{array}$ & $\begin{array}{l}\sigma \mathrm{B} \\
\text { when } \mathrm{k}_{1} \leq \mathrm{A} \text { and } \sigma>1\end{array}$ \\
\hline
\end{tabular}




\section{Efficient governance structure}

This section formulates results regarding the efficient governance structure choice in the first stage of the game. Efficiency of a governance structure entails that the sum of the payoffs of the three players in this governance structure is at least as high as the sum of the payoffs of the three players in any other governance structure. We limit ourselves to the case $\mathrm{k}_{1} \leq \mathrm{A}$ and $\sigma>1$.

The efficient governance structure choice, and its feasibility, is determined by figure 3. All governance structures are efficient in the north-east rectangle, i.e. they all result in a surplus of A-k $\mathrm{k}_{1}$. The franchisor is the only party investing in specific assets because its costs of investment are sufficiently low. Governance structure III is the unique efficient governance structure in the north-west and north rectangle (because $\sigma \mathrm{B}$ $\mathrm{k}_{2}>\mathrm{B}-\mathrm{k}_{2}>0$ ). The franchisor invests again in every governance structure. Franchisee $\mathrm{C}$ never invests when $\mathrm{k}_{3}>\sigma \mathrm{C}$ because the costs of investment are too high. This is efficient. Franchisee B does not invest in the governance structures I and II because there is no incentive to invest due to the lack of power. These governance structures are inefficient because the value generated by franchisee B is larger than its costs. However, franchisee B invests in the governance structures III and IV because sufficient power is allocated to this franchisee. Governance structure III is the unique efficient governance structure because it generates the dual distribution externality, whereas governance structure IV does not. A similar reasoning applies to governance structure II being uniquely efficient in the east and south-east rectangle.

Governance structure I is never efficient in the remaining four rectangles, while governance structure IV is only efficient for certain parameter values in the south-east rectangle. Governance structure IV is efficient when $\sigma \mathrm{B}-\mathrm{k}_{2}<\mathrm{B}-\mathrm{k}_{2}+\mathrm{C}-\mathrm{k}_{3}$ and $\sigma \mathrm{C}-\mathrm{k}_{3}<\mathrm{B}-$ $\mathrm{k}_{2}+\mathrm{C}-\mathrm{k}_{3}$, i.e. $\mathrm{k}_{3}<\mathrm{C}-(\sigma-1) \mathrm{B}$ and $\mathrm{k}_{2}<\mathrm{B}-(\sigma-1) \mathrm{C}$. Figure 4 presents the situation where $\mathrm{B}-$ $(\sigma-1) \mathrm{C}<0$, i.e. there are substantial positive dual distribution externalities. ${ }^{6}$ There are no parameter values for which governance structure IV is the unique efficient governance structure. The intermediate investment incentives for both franchisees in governance structure IV are not strong enough to override the strong investment incentives for either franchisee B in governance structure III or franchisee C in governance structure II.

\footnotetext{
${ }^{6}$ The upward sloping line in the figures 2 and 3 is characterized by $k_{3}=\sigma(C-B)+k_{2}$.
} 


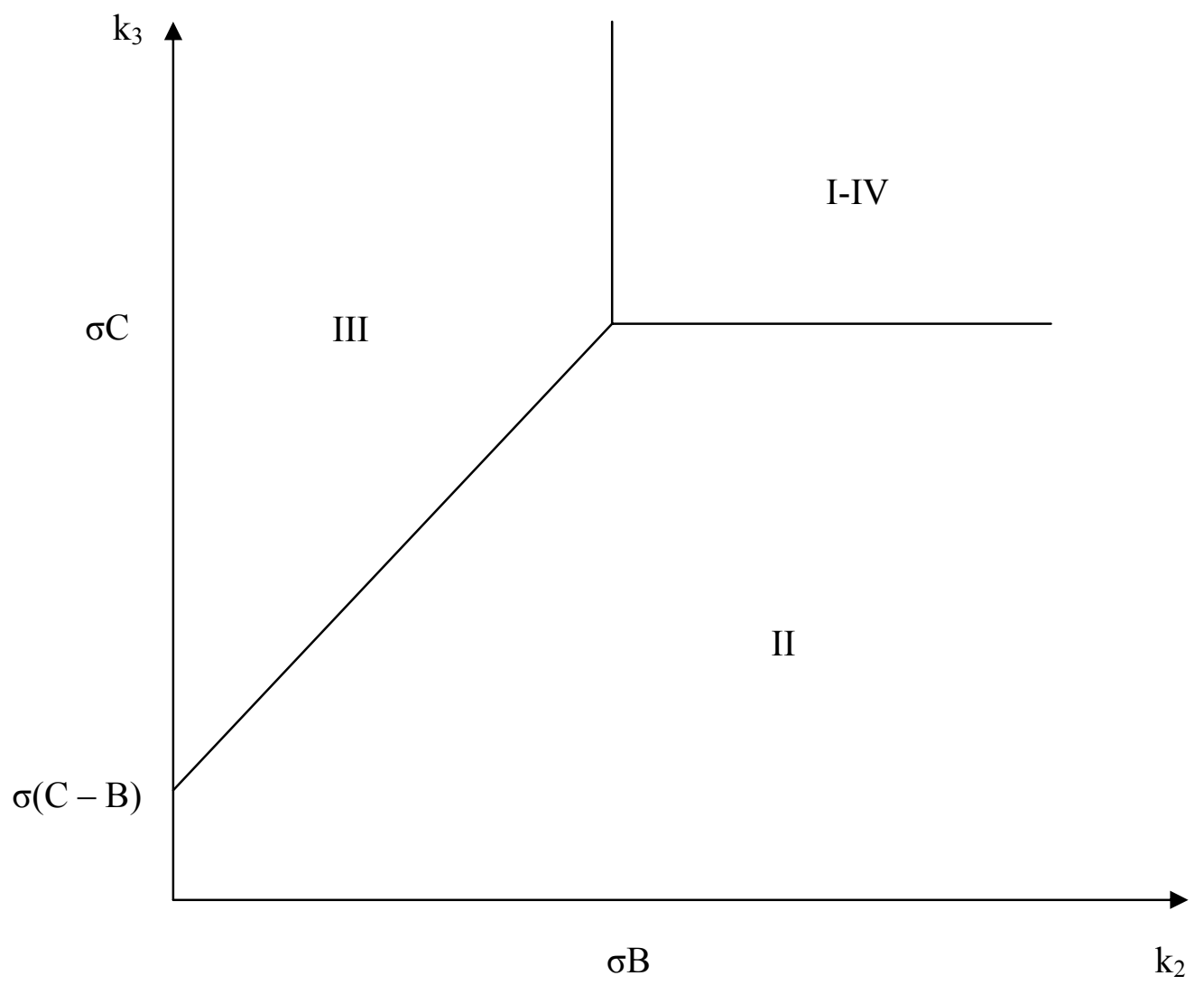

Figure 4: Efficient governance structures when $\sigma \geq 1+\mathrm{B} / \mathrm{C}$

Governance structure II is the unique efficient governance structure in the southeast. It discourages efficiently investment by franchisee B with its relatively high costs of investment, while franchisee $\mathrm{C}$ invests and generates the dual distribution externality. The reverse holds in the north-west. Governance structure III is efficient because discourages investment by franchisee $\mathrm{C}$ with its relatively high costs of investment, while franchisee $\mathrm{C}$ invests and generates the dual distribution externality.

Figure 5 presents the efficient governance structure choices when B- $(\sigma-1) \mathrm{C}>0$. The intermediate investment incentives for both franchisees in governance structure IV create more value than the strong investment incentive for either franchisee $\mathrm{B}$ in governance structure III or franchisee $\mathrm{C}$ in governance structure II when the plural form externality is limited. 




Figure 5: Efficient governance structures when $1<\sigma<1+\mathrm{B} / \mathrm{C}$

The above results will now be summarized in a number of results.

Result 1: Governance structure I is never a unique efficient governance structure.

Explanation: The franchisees have no power in governance structure I, and therefore no incentive to invest. Governance structure $I$ is only as efficient as the other governance structures when the costs of investment discourage investment by all franchisees in all governance structures.

Result 2: Governance structure II is the unique efficient governance structure choice when $\sigma>1, \mathrm{k}_{2}$ is above a certain level, and $\mathrm{k}_{3}$ is below a certain level.

Explanation: Franchisee B will not invest because its costs of investment are too high, regardless whether it has power or not. The costs of investment of franchisee $\mathrm{C}$ are low, but some power is needed in order to cover these costs. Governance structures III and IV remain. Governance structure III strictly dominates governance structure IV when there are positive plural form externalities, i.e. $\sigma>1$. 
Result 3: Governance structure III is the unique efficient governance structure choice when $\sigma>1, \mathrm{k}_{2}$ is below a certain level and $\mathrm{k}_{3}$ is above a certain level.

Explanation: Similar to the explanation of result 2.

Result 4: Governance structure IV is the unique efficient governance structure choice when $\mathrm{k}_{2}$ and $\mathrm{k}_{3}$ are small and $\sigma<1+\mathrm{B} / \mathrm{C}$.

Explanation: The attractiveness of governance structure IV is that both franchisees have an incentive to invest because each of them has power. However, the positive plural form externality is not captured. Governance structures II and III have the advantage of generating the positive plural form externality, but only the independent franchisee invests. The value of having both franchisees investing dominates the generation of the plural form externality by one investing franchisee when plural form externality is not too high.

Result 5: Governance structure IV is never a unique efficient governance structure choice when $\sigma>1+\mathrm{B} / \mathrm{C}$.

Explanation: The reverse of the explanation of result 4.

Result 6: Plural form franchising, i.e. either governance structures II or III, is the unique efficient governance structure for the parameter values specified in the results 2 and 3, even when $\mathrm{B}=\mathrm{C}$.

Explanation: This result covers special cases of the results 2, 3 and 5. The value generated by the independent franchisee in a plural form governance structure is higher than the value generated by either one or two franchisees in governance structure IV. This result shows that it is not necessary for the emergence of the plural form that there are locational differences, or other differences between the franchisees. System wide externalities are responsible for the plural form being a unique, efficient governance structure.

Result 7: If $\sigma=1$, then governance structure IV is efficient for all values of the parameters $\mathrm{k}_{2}$ and $\mathrm{k}_{3}$.

Explanation: Figure 6 illustrates the result. Governance structure IV is always efficient because the incentive to invest for each franchisee in governance structure IV is always at least as strong as in the governance structures I-III. This result indicates that the positive plural form externality is crucial for a plural form governance structure to be a unique, efficient governance structure. 


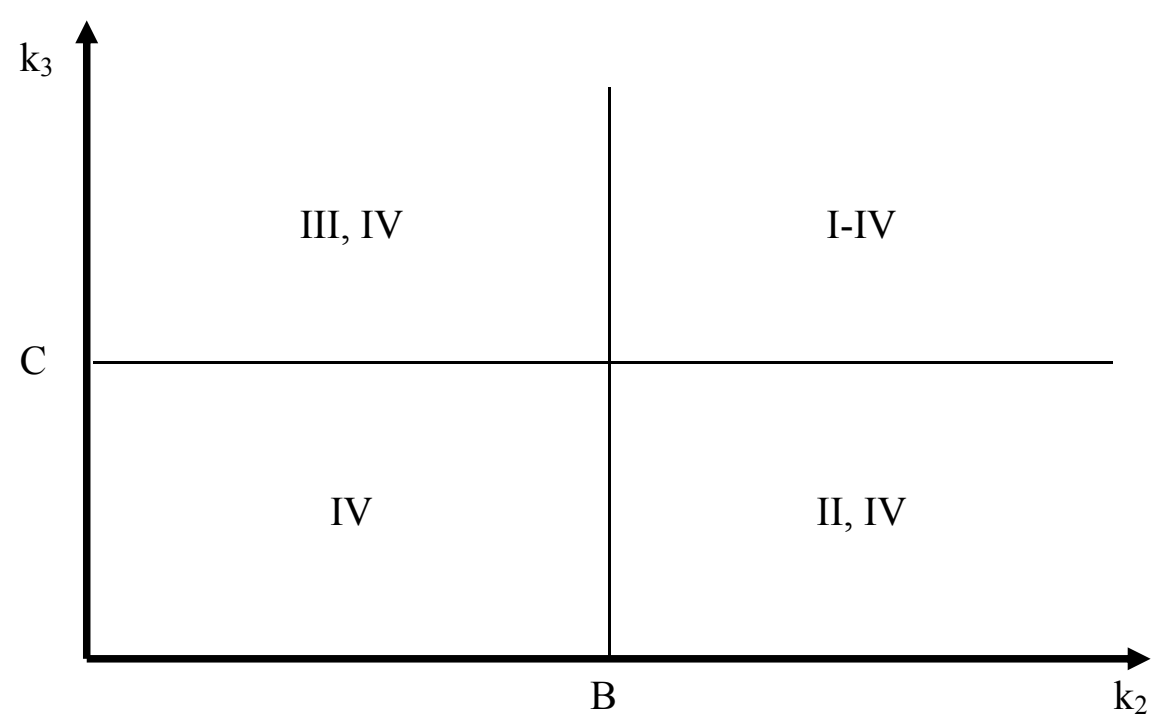

Figure 6: Efficient governance structure choice when $\sigma=1$

\section{Conclusions and further research}

Lutz $(1995,129)$ stated: 'A multiple unit model can determine whether locational differences are necessary for dual distribution, or whether dual distribution can arise as a solution for incentive problems even when all units are ex ante identical. The most important extension will be to examine the choice of ownership for individual units within a multiple-unit chain. Since we observe franchise relationships almost exclusively in these chains, this extension is crucial for developing empirical predictions'. We have presented a multiple unit model with the plural form being a unique, efficient governance structure. Not locational or other differences between units are necessary for the emergence of plural form franchising, but positive externalities being specific for the plural form.

Our model is too simple to capture the richness of franchising practices. For example, Lutz $(1995,129)$ continued: 'Such a multiple-unit model should have several key features. First, at least some of the central firm's effort creates a public good: improvements in the trademark will increase profits at all stores in the chain. Second, any local manager's action may also affect the profits at other units: this will be the case when a local manager's action affects the value of the trademark. Thus incentives for all parties are interdependent.' These two features are not incorporated is the current model. However, these and other several extensions are possible.

First, notice that the parameter $\sigma$ depends in the current model on governance structure, but in rudimentary way because $\sigma(\mathrm{G})=\sigma$ when $\mathrm{G}=\mathrm{II}$, III or $\sigma(\mathrm{G})=1$ when $\mathrm{G}=\mathrm{I}$, IV. There are various possibilities to model the parameter $\sigma$ as the outcome of an equilibrium process, where $\sigma$ is either smaller, or equal, or larger than one, like the modeling of 'ratcheting' by the literature regarding relative compensation (Lazear and Rosen, 1981 and Green and Stokey, 1983), or complementarities along the lines of Bradach (1997) by the systems of attributes literature (Holmstrom and Milgrom, 1991 and 1994). This extension entails that an additional stage is added between the current 
two stages of the game. Second, the percentage of company owned outlets can be only one of three levels in our model in the various governance structures, i.e. $0 \%$ (IV), $50 \%$ (II, III), or $100 \%$ (I). Incorporating more sellers will allow for more variability regarding the percentage of company owned outlets.

Third, the focus has been on the allocation of decision rights. However, many authors refer to the monitoring and free riding problems in franchising. The relationship between these income rights aspects of franchising and the plural form has to be determined. A similar observation holds regarding the use of royalty rates. Fourth, the extent of incompleteness is not endogenous. A franchise has to decide how much discretion is assigned to the activities of the franchisees. The standard way of dealing with this issue in franchises is the choice of the business format. Given the business format content in our model and making it endogenous along the lines of Tadelis (2002) is a challenging line of research. The extent of coverage of the business format may turn out to vary with the choice of governance structure.

Fifth, Lafontaine and Shaw (2005) highlight the importance of the trademark in dual distribution franchises. Their empirical evidence indicates that there is a strong tendency that the number of company-owned outlet increases when the value of the brand/trademark (A) increases. The comparative statics results in the current model are independent of the value (A) of the brand. However, if other governance structures are also taken into consideration, e.g. mirror images regarding authority of governance structures I-III in figure 2, then our model may be able to account for this relationship between the value of the brand and governance structure choice. This will be a topic for future research. 


\section{References}

Bradach, J. L. (1997). "Using the Plural Form in the Management of Restaurant Chains." Administrative Science Quarterly 42: 276 - 303.

Bradach, J. L. (1998). “Franchise Organisation.” Harvard Business School Press.

Brickley, J. A., F. H. Dark, and M. S. Weisbach, (1991). "An Agency Perspective on Franchising." Financial Management 20(1): 27.

Caves R. E. and W. F Murphy II, (1976). "Franchising: Firms, Markets, and Intangible Assets.” Southern Economic Journal (pre-1986) 42(1-4): 572.

Cliquet, G. and M-N. Nguyen, (2004). "Innovation Management within the Plural Form Network." In Windsperger J., Cliquet G., Hendrikse G., Tuunanen M. (eds): Economics and Management of Franchising Networks. Physica-Verlag, Heidelberg.

Combs J. G., S. C. Michael and G. J. Castrogiovanni, (2004). "Franchising: A Review and Avenues to Greater Theoretical Diversity.” Journal of Management, 30(6): 907-931.

Dnes, A. W., (1993). "A case-study analysis of franchise contracts." Journal of Legal Studies 22: 367-394.

Dnes A. and N. Garoupa, (2005). "Externality and organizational choice in franchising." Journal of Economics and Business 57 (2): 139-149.

Franchise Funding website, http://www.franchisefunding.net/fran_industry_info.html, 2004.

Gallini, N. T. and N. A. Lutz, (1992). "Dual Distribution and Royalty Fees in Franchising." Journal of Law, Economics, and Organization 8 (October): 471-501.

Green J. R. and N. L. Stokey, (1983). “A Comparison of Tournaments and Contracts.”, Journal of Political Economy 91: 349-364.

Grossman, S. and O. Hart, (1986). "The costs and benefits of ownership: A theory of vertical integration and lateral integration.” Journal of Political Economy 94: 691-719.

Hart, O.D. and J. Moore, (1990). "Property Rights and the Nature of the Firm." Journal of Political Economy 98: 1119-1158.

Hart, O., (1995). "Firms, Contracts, and Financial Structure", Clarendon Press, Oxford.

Hansmann, H., (1996). “The Ownership of Enterprise.” The Belknap Press of Harvard University Press. 
Hendrikse, G. W. J. and J. Windsperger, (2004). "Introducing 'Economics and Management of Franchising Networks." In Windsperger J., Cliquet G., Hendrikse G., Tuunanen M. (eds): Economics and Management of Franchising Networks. PhysicaVerlag, Heidelberg: 1-13.

Holmstrom, B. and P. Milgrom, (1991). "Multitask Principal-Agent Analyses: Incentive Contracts, Asset Ownership and Job Design." Journal of Law, Economics and Organization 7 (special issue), 24-52.

Holmstrom, B. and P. Milgrom, (1994). "The Firm as an Incentive System.” American Economic Review 84(4): 972-991.

Klein, B., (1980). "Transaction Costs Determinants of Unfair Contractual Arrangements.” American Economic Review 70(2): 356-362.

Lafontaine, F, (1993). "Contractual arrangements as signalling devices: Evidence from franchising." Journal of Law, Economics, and Organization 9: 256-289.

Lafontaine, F. and K.L. Shaw, (2005). "Targeting Managerial Control: Evidence from Franchising.” Rand Journal of economics 36(1): 131-150.

Lazear, E. P. and S. Rosen, (1981). "Rank-Order Tournaments as Optimum Labor Contracts." Journal of Political Economy 89 (5): 841-864.

Lewin, S. B., (1999). "Innovation and authority in franchise systems: An empirical exploration of the plural form." working paper, University of Cambridge and Iowa State University.

Lutz, N.A., (1995). "Ownership Rights and Incentives in Franchising." Journal of Corporate Finance 2: 103-131.

Mathewson, G. F. and R. A. Winter, (1985). "The economics of franchise contracts." Journal of Law and Economics 28: 503-526.

Mathewson, G.F. and R. Winter, (1994). "Territorial Restrictions in Franchise Contracts.” Economic Inquiry 32 (2): 181-192.

Michael, S. C., (1996). "To Franchise or Not To Franchise: An Analysis of Decision Rights and Organizational Form Shares.” Journal of Business Venturing 11(1): 57.

Norton, S. W., (1988). "An Empirical Look at Franchising as an Organizational Form." The Journal of Business 61(2): 197.

Oxenfeldt, A. R. and A. O. Kelly, (1968-69). "Will Successful Franchise Systems Ultimately Become Wholly-Owned Chains?” Journal of Retailing 44: 69-83. 
Rubin, P. H., (1978). "The theory of the firm and the structure of the franchise contract." Journal of Law and Economics 21: 223-233.

Saloner, G., A. Shephard, and J. Podolny, (2001). "Strategic Management”, Wiley.

Scott, F. A., (1995). "Franchising vs. Company Ownership as Decision Variable of the Firm." Review of Industrial Organization 10: 69-81.

Shapley, L. S., (1953). “A value for n-person games.” In Kuhn,H. W., and Tucker, A. W., (eds), Contributions to the Theory of Games, Volume II of Annals of Mathematics Studies 28. Princeton University Press: 307-317.

Sorenson, O. and J. B. Sorensen, (2001). "Finding the Right Mix: Franchising, Organizational Learning, and Chain Performance.” Strategic Management Journal 22: 713-724.

Tadelis, S., (2002). "The Market for Reputations as an Incentive Mechanism." Journal of Political Economy 92 (2): 854-882

Williamson, O. E., (1981). "The modern corporation: Origins, evolution, attributes." Journal of Economic Literature 19: 1537-1568.

Windsperger, J. (2004). "The Dual Network Structure of Franchising Firms: Property Rights, Transaction Costs and Resource Scarcity Explanations." In Windsperger J., Cliquet G., Hendrikse G., Tuunanen M. (eds): Economics and Management of Franchising Networks. Physica-Verlag, Heidelberg.

Windsperger, J. and A.Yurdakul, (2005). "Exploring the Relationship between Knowledge Assets, Decision Rights and Ownership Rights: The Governance Structure of Franchising Firm." Working paper, University of Vienna. 


\section{Appendix 1: Extensive form}

The first stage of the game consists of the choice of governance structure. There are four possible choices. The second stage of the game consists of the investment decisions of the three players. Each player decides between investing or not investing in specific assets. The sequence of their decisions does not matter in our specification of the payoffs. We depict the choice of the franchisor first, subsequently the choice of franchisee B, and finally the choice of franchisee $C$. The total number of choice sequences is therefore $4 \times 2 \times 2 \times 2=32$. The extensive form is presented in the figures $7-10$ due to this large number of possible decision sequences. The payoffs are based on table 2. The payoffs below branch YYY are composed of revenues and costs. The revenues are taken straight from table 2, while each player carries it costs of specific investments. Similarly, branch NYN corresponds to investment vector $(0,1,0)$, i.e. only franchisee $\mathrm{B}$ invests. Benefit $\mathrm{B}$ is generated and taken by the franchisor, while franchisee $\mathrm{B}$ carries the costs $\mathrm{k}_{2}$.

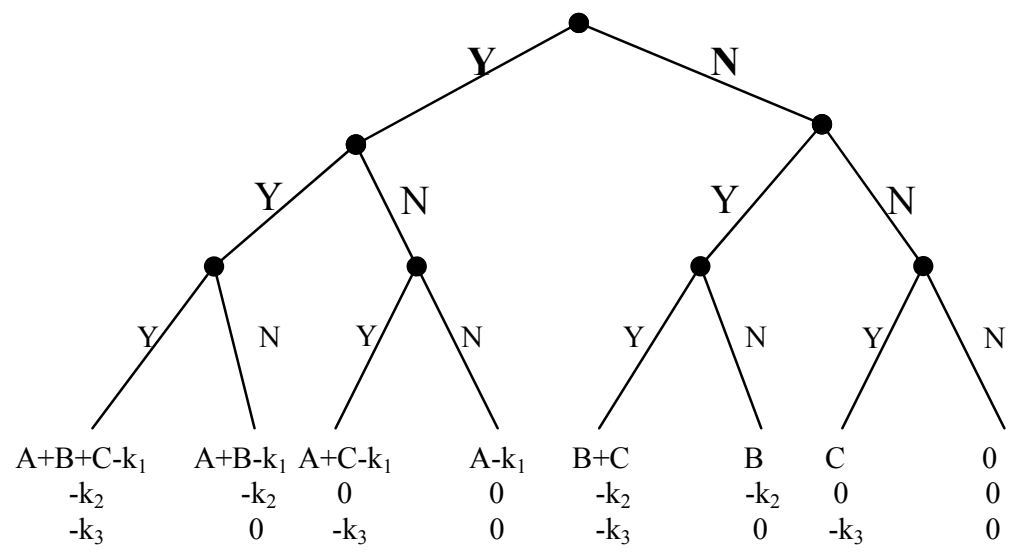

Franchisor

Investment choice

Franchisee B

Investment choice

Franchisee C

Investment choice

Figure 7: Extensive form when governance structure I has been chosen 


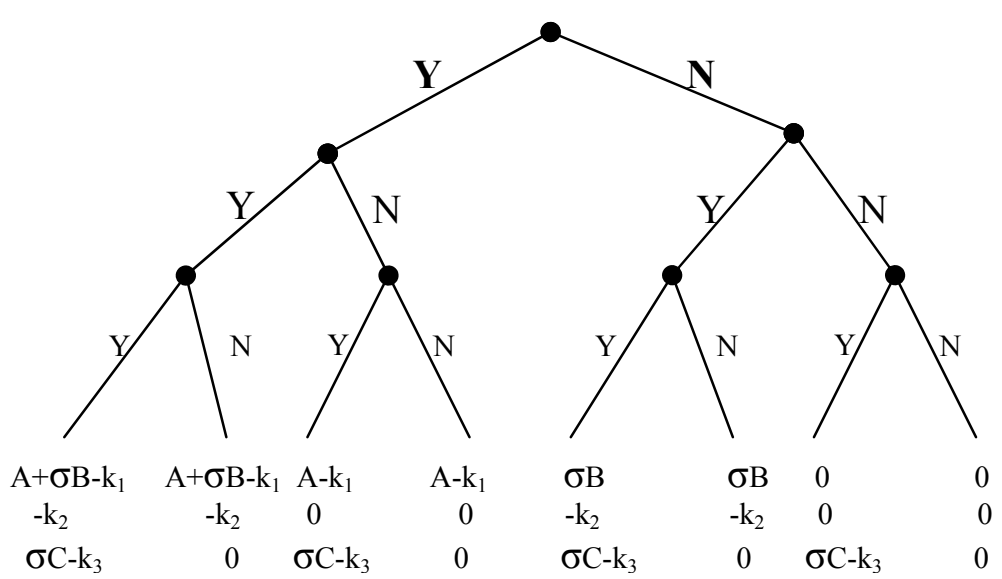

\section{Franchisor}

Investment choice

Franchisee B

Investment choice

\section{Franchisee $\mathbf{C}$}

Investment choice

Figure 8: Extensive form when governance structure II has been chosen

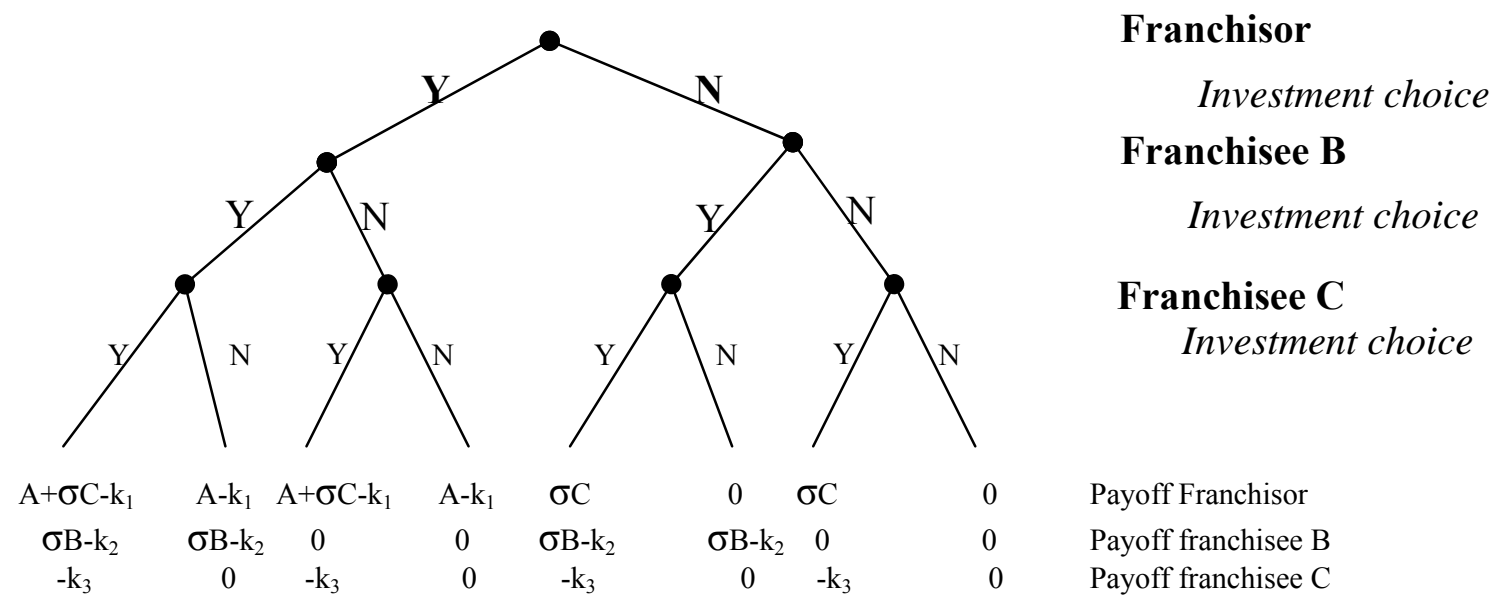

Figure 9: Extensive form when governance structure III has been chosen 


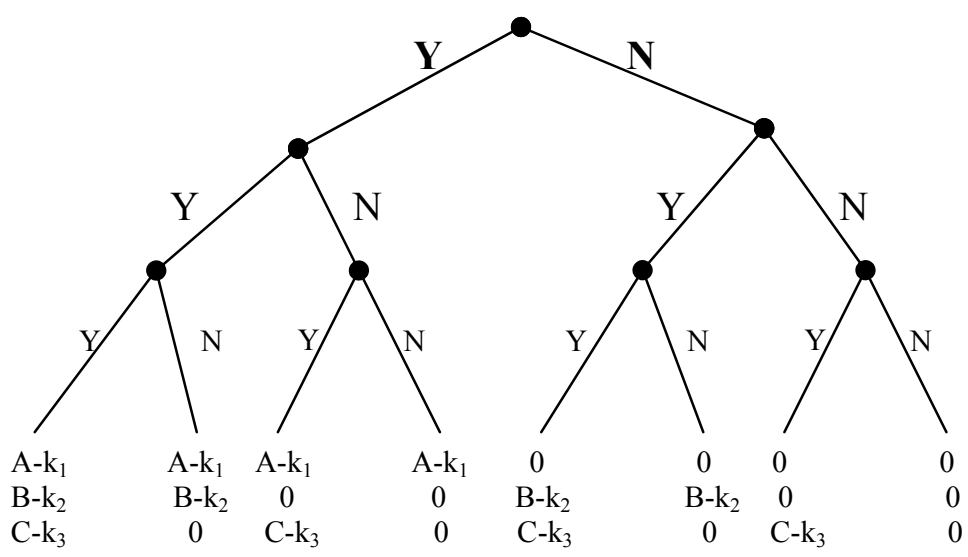

\section{Franchisor}

Investment choice

Franchisee B

Investment choice

\section{Franchisee C}

Investment choice

Figure 10: Extensive form when governance structure IV has been chosen 
Appendix 2: Subgame perfect equilibrium payoffs when $\sigma<1$

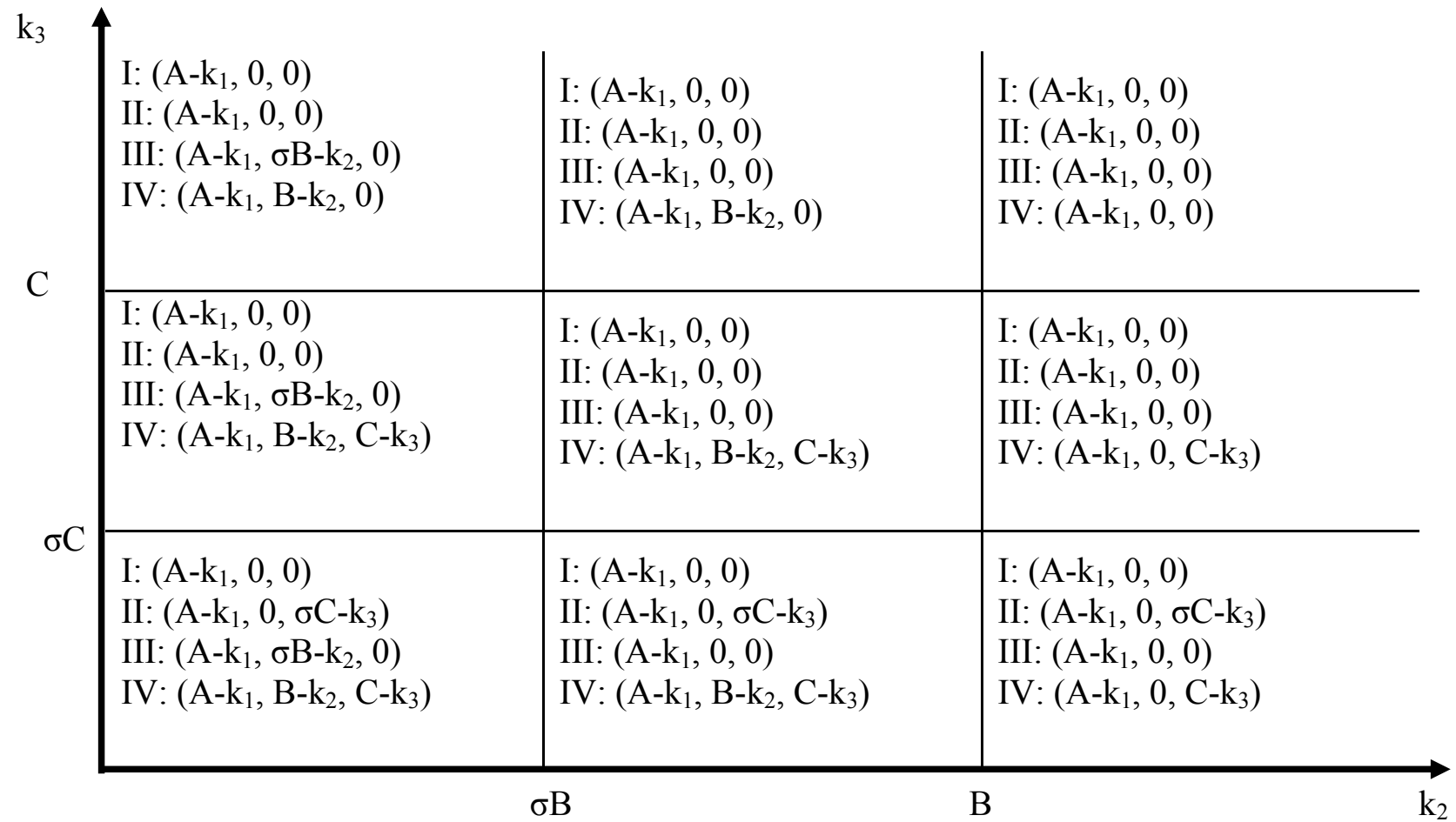

Figure 11: Subgame perfect equilibrium payoffs when $\mathrm{k}_{1} \leq \mathrm{A}, \sigma<1$ 


\section{Publications in the ERIM Report Series Research* in Management}

\section{ERIM Research Program: "Organizing for Performance"}

\section{5}

Continuous versus Step-Level Public Good Games

Susanne Abele and Garold Stasser

ERS-2005-015-ORG

http://hdl.handle.net/1765/1937

Collective Consuming: Consumers as Subcontractors on Electronic Markets

Wilfred Dolfsma

ERS-2005-020-ORG

http://hdl.handle.net/1765/1932

Appropriability in Services

Wilfred Dolfsma

ERS-2005-021-ORG

http://hdl.handle.net/1765/1926

Is China a Leviathan?

Ze Zhu and Barbara Krug

ERS-2005-031-ORG

http://hdl.handle.net/1765/6551

Information Sharing and Cognitive Centrality

Susanne Abele, Garold Stasser and Sandra I. Vaughan-Parsons

ERS-2005-037-ORG

http://hdl.handle.net/1765/6664

Virtual Enterprises, Mobile Markets and Volatile Customers

Ferdinand Jaspers, Willem Hulsink and Jules Theeuwes

ERS-2005-039-ORG

http://hdl.handle.net/1765/6728

No Black Box and No Black Hole: from Social Capital to Gift Exchange

Rene van der Eijk, Wilfred Dolfsma and Albert Jolink

ERS-2005-040-ORG

http://hdl.handle.net/1765/6665

Boards in Agricultural Cooperatives: Competence, Authority, and Incentives

G.W.J. Hendrikse

ERS-2005-042-ORG

http://hdl.handle.net/1765/6883

Finding Team Mates who are not prone to Sucker and Free-Rider effects: The Protestant Work Ethic as a Moderator of Motivation Losses in Group Performance

Susanne Abele and Michael Diehl

ERS-2005-053-ORG

http://hdl.handle.net/1765/6990

Organization and Strategy of Farmer Specialized Cooperatives in China

Yamei Hu, Zuhui Huang, George Hendrikse and Xuchu Xu

ERS-2005-059-ORG

http://hdl.handle.net/1765/6995 
The Influence of Employee Communication on Strategic Business Alignment

Cees B. M. van Riel, Guido Berens and Majorie Dijkstra

ERS-2005-060-ORG

http://hdl.handle.net/1765/6996

The Tsunami's CSR Effect: MNEs and Philanthropic Responses to the Disaster

Gail Whiteman, Alan Muller, Judith van der Voort, Jeroen van Wijk, Lucas Meijs and Cynthia Piqué ERS-2005-062-ORG

http://hdl.handle.net/1765/6994

Bridging Structure and Agency: Processes of Institutional Change

Wilfred Dolfsma and Rudi Verburg

ERS-2005-064-ORG

http://hdl.handle.net/1765/7014

Accounting as Applied Ethics: Teaching a Discipline

Wilfred Dolfsma

ERS-2005-065-ORG

http://hdl.handle.net/1765/7021

Institutions, Institutional Change, Language, and Searle

John Finch, Robert McMaster and Wilfred Dolfsma

ERS-2005-067-ORG

http://hdl.handle.net/1765/7109

Reflexivity in Teams: A Measure and Correlates

Michaéla C. Schippers, Deanne N. den Hartog and Paul L. Koopman

ERS-2005-069-ORG

http://hdl.handle.net/1765/7117

The Role of Team Leadership in Enhancing Team Reflexivity and Team Performance Michaéla C. Schippers, Deanne N. den Hartog, Paul L. Koopman and Daan van Knippenberg ERS-2005-070-ORG

The Psychological Benefits of Superstitious Rituals in Top Sport

Michaéla C. Schippers and Paul A.M. Van Lange

ERS-2005-071-ORG

http://hdl.handle.net/1765/7118

The Impact of New Firm Formation on Regional Development in the Netherlands

André van Stel and Kashifa Suddle

ERS-2005-075-ORG

http://hdl.handle.net/1765/7131

Allocation and Productivity of Time in New Ventures of Female and Male Entrepreneurs Ingrid Verheul, Martin Carree and Roy Thurik

ERS-2005-082-ORG

http://hdl.handle.net/1765/7178

Internationalization and Performance: The Moderating Role of Strategic Fit

Fabienne Fortanier, Alan Muller and Rob van Tulder

ERS-2005-083-ORG

http://hdl.handle.net/1765/7170

Exploring Patterns of Upstream Internationalization: The Role of Home-region 'Stickiness'

Alan Muller and Rob van Tulder

ERS-2005-084ORG

http://hdl.handle.net/1765/7174 
The Search for Synergy between Institutions and Multinationals: Institutional Uncertainty and Patterns of Internationalization Alan Muller and Rob van Tulder

ERS-2005-086-ORG

http://hdl.handle.net/1765/7189

Is China a Leviathan? (revised)

Ze Zhu and Barbara Krug

ERS-2005-087-ORG

http://hdl.handle.net/1765/7175

China's Emerging Tax Regime: Local Tax Farming and Central Tax Bureaucracy

Ze Zhu and Barbara Krug

ERS-2005-087-ORG

http://hdl.handle.net/1765/7188

Explaining Female and Male Entrepreneurship at the Country Level Ingrid Verheul, André van Stel and Roy Thurik

ERS-2005-089-ORG

http://hdl.handle.net/1765/7172

Plural Form in Franchising: An Incomplete Contracting Approach

George Hendrikse and Tao Jiang

ERS-2005-090-ORG

* A complete overview of the ERIM Report Series Research in Management: https://ep.eur.n//handle/1765/1

ERIM Research Programs:

LIS Business Processes, Logistics and Information Systems

ORG Organizing for Performance

MKT Marketing

F\&A Finance and Accounting

STR Strategy and Entrepreneurship 